Ключевые слова: профессиональная деятельность; системное познания мира; социально-воспитательная среда; социально-педагогическая деятельность; социально-педагогическая система.

\title{
METHODOLOGICAL ANALYSIS OF SOCIAL AND PEDAGOGICAL ACTIVITY
}

Budnyk Olena, Doctor of Pedagogical Sciences, Head of Chair of Theory and Methods of Primary Education, Vasyl Stefanyk Precarpathian National University, 57 Shevchenko str.,

76018 Ivano-Frankivsk, Ukraine, budolen@yahoo.com

Vasianovych Hryhorii, Doctor of Pedagogical Sciences, Professor, Director, Lviv Scientific and Practical Centre of the Institute of Professional and Technical Education of the National Academy of Pedagogical Sciences of

Ukraine, 10 M. Kryvonosa str., 79008 Lviv, Ukraine, smetanochka@ukr.net

The article grounds essential characteristics of social and pedagogical activity in methodological aspect based on the principles of reality cognition concerning the unity of theory and practice, environmental, system and activity approaches, value-meaningful understanding of its results etc. The authors proposes the definition of social and pedagogical activity of a teacher basing on the philosophical, psychological, social and pedagogical theories of the activity. Integrative result of social and pedagogical activity defined sociality as complex characteristic of its subject that is formed and developed in the family, educational establishments, ethnic, labor and professional communities.

Teacher's social and pedagogical activity is treated by the authors as sort of his/her professional activity that is aimed at making appropriate conditions for successful pupils socialization in socio-cultural environment of school, their acquiring of social experience on behalf of preparing to self-realization in the society, giving appropriate help to children and their families. The authors consider the main purpose of the realization of social and pedagogical activity of a teacher in organizing the society as pedagogically oriented environment for individual and group socio-cultural education of pupils. Consequently, the result of such an activity is the level of readiness in pupils' social qualities, self-consciousness and self-affirmation that are acknowledged in social and educational surrounding of educational establishment as the constituents of vital activity in the society.

Key words: professional activity of a teacher; social and educational system; social and pedagogical activity; social-educational environment; systematic cognition of a world.

Стаття надійшла до редакції 28.01.2016 Прийнято до друку 31.03.2016

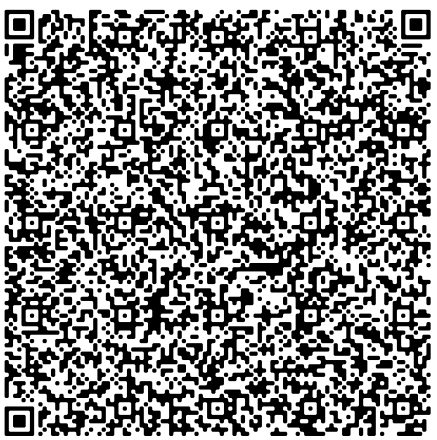

УДК 373.5:37.014.5

Костянтин Линьов

ORCID iD 0000-0002-3162-3900

кандидат наук з державного управління, доцент, професор кафедри управління,

Київський університет імені Бориса Грінченка, пр-т М. Тимошенка 13 б, 04212 м. Київ, Україна,

k.lynov@kubg.edu.ua

\section{КОНЦЕПЦІЯ РОЗВИТКУ ЗАКЛАДУ СЕРЕДНЬОЇ ОСВІТИ НА ЗАСАДАХ ЛІДЕРСТВА}

Стаття присвячена виявленню спещифіки розробки Конщепџї розвитку закладу середнвої освіти в Україні на засадах лідерства. Спираючись на модель послідовних кроків «Чотири імперативи лідерства» Стівена Кові - старшого, автор пропонує структуру Концепиї розвитку закладу середньої освіти та алгоритм ї розробки і реалізацї. Наголошується, що запровадження лідерської парадигми у діяльність закладу середньої освіти характеризується посиленням значення горизонтальних зв'язків, делегуванням повноважень, фокусуванням на талантах, спроможностях співробітників, їх компетентностях.

Ключові слова: візія; заклад середньої освіти; Концепція розвитку закладу середньої освіти; лідерство; місія; модель послідовних кроків.

Вступ. Академічна і фінансова автономія школи, дотримання принципу відповідальності навчальних закладів за результати своєї діяльності, прописані у Проекті Концепції розвитку освіти України на 2015- 
2025 роки (Проект Концепцї, 2015), актуалізує потребу у розробці та реалізації Концепції розвитку закладу середньої освіти. Відкритий відбір кандидатур на заміщення вакантних посад керівників загальноосвітніх та дошкільних навчальних закладів Києва, який запроваджено з червня 2015 року, показав, що кращі результати та здатності до управлінської діяльності мають ті претенденти, які демонструють наявність бачення майбутнього закладу освіти, розуміють потребу у командоутворенні, відкриті до змін. Одним з головних критеріїв відбору стали результати досліджень лідерських якостей претендентів.

Запровадження лідерської парадигми в управлінні закладом середньої освіти (у подальшому - 3СО) є критично важливим тоді, коли з'являється необхідність у перетвореннях. Мотивація співробітників до розвитку лідерських якостей та прояву ініціативи передбачає, що у них з'являється відчуття причетності до результатів колективної діяльності, що доповнюється самодисципліною. Все це створює культуру свободи та відповідальності у ЗСО, допомагає розвивати особистість учня, формувати його готовність до життя у XXI столітті.

Феномен лідерства досліджується у роботах Б. Басса, У. Бенніса, Дж. Бернса, Д. Велча, Р. Грінліфа, Р. Хамфрі, А. Харріс та ін. Впровадженню лідерства у закладах освіти присвячені роботи Т. Буша, Б. Девіса, П. Ерлі, Ф. Інгліша, К. Лейтвуда, М. Лінча, Дж. Мерфі, Р. Паркера та ін. Серед вітчизняних дослідників виділяються роботи С. Калашнікової.

Проблематику стратегічного управління школою досліджували О. Мармаза, О. Перехейда, Л. Калініна та Т. Капустерінська. Безпосередньо концепцією розвитку закладу освіти опікувалася В. Григораш.

Метою статті є виявлення специфіки розробки Концепції розвитку ЗСО (у подальшому - Концепція) на засадах лідерства. Для реалізації мети автор ставить перед собою завдання визначити структуру Концепції та дослідити алгоритм її розробки та реалізації на засадах лідерства.

Лідерська парадигма управління. Лідерство як суспільний феномен досліджується багатьма дослідниками протягом тисячоліть. Характерним було ототожнення лідерства з певною позицією людини в ієрархії, їі посадою, роллю, яка сприяла успіху та ефективності в державно-управлінській структурі. Подібне розуміння лідерства фокусувало увагу на головній ролі особистості лідера, розглядаючи послідовників як щось пасивне чи другорядне. Така постановка питання сама по собі обмежує кількість осіб, здатних вважатися лідерами, і чітко вказує на урядовців високого рівня чи на ТОПменеджмент у великій корпорації.

Сучасні теорії лідерства суттєво відрізняються від попередніх (Belinskaja L., Pauliene R., 2012), вони виникають у певну історичну епоху, у суспільстві, що переходить до інформаційної стадії свого розвитку, як спосіб управління нестандартними та творчими особистостями (Линьов К. О., 2015 , c. 130-131). Кожна суспільна формація привносила свої вимоги до лідера. Індустріальне суспільство грунтується на машинному та серійному виробництві, а тому формувало специфічний спосіб мислення, міркування та сприйняття. I парадигмою управління в індустріальну епоху, в умовах промислової, технологічної революції, виступав менеджмент, як спосіб наведення порядку та контролю в ієрархічних організаціях.

Інформаційне суспільство характеризується зростанням кількості людей, зайнятих інформаційними технологіями, комунікаціями і виробництвом інформаційних продуктів і послуг; зростанням частки інформаційних продуктів і послуг у валовому внутрішньому продукті. Це призводить до домінуючої ролі у суспільстві творчості, нестандартності, зростає значення цінностей та моралі. Людина стає вирішальним фактором виробництва. I якщо символами індустріальної епохи можна визначити верстат і дисциплінованість, виконавчу майстерність працівника, то символами інформаційної епохи стають комп'ютер і творчість людини.

Лідерство є критично важливим тоді, коли в організації з'являється необхідність у змінах. Дж. Бернс, один з авторів теорії трансформаційного лідерства, писав: «Лідерство передбачає трансформацію, перетворення людей та організацій, а не просто мотивування співробітників працювати в обмін на заробітну плату. Концепція лідерства зачіпає моральний аспект нашого життя та демонструє, як окрема людина, взаємодіючи з групою інших людей, може сприяти перебудові організації, що в свою чергу може призвести до змін у суспільстві» (Максвелл Дж., 2013, с. 9).

У своїй роботі автори зазначають: «Якщо ви хочете зрозуміти сутність лідерства, не зосереджуйтесь виключно на особистісних характеристиках. Лідерство - це подія, а не риса характеру. Сутність цього феномену полягає скоріше у тому, що людина робить з самим собою, ніж просто в тому, хто вона є. Коротше, лідерство, по-перше, передбачає розуміння вами своїх сильних та слабких сторін i, по-друге, прийняття ролей та обов'язків, які формують між вами та вашими послідовниками особливі стосунки» (Бойетт Дж., Бойетт Дж., 2009, с. 24). «Справжній лідер розвиває лідерські якості не тільки у себе, але й у оточуючих його людей, щоб разом здійснити перетворення, які позитивно впливають на наше життя» (Оуэн Х., Ходжсон В., Газзард Н., 2005, с. 54).

Лідерство грунтується на довірі, остання в свою чергу є частиною структури і культури організації та здійснює на них вплив. Організація з високим рівнем довіри базується на відкритості, відвертості та цілісності. Довіра народжується та проявляється у нас самих, у наших думках, діях, рішеннях. 
Роберт Купер писав: «Довіра починається з почуття власної гідності та цілеспрямованості, яке ми проектуємо назовні, на оточуючих нас людей...» (Оуэн Х., Ходжсон В., Газзард Н., 2005, с. 156).

Більшість сучасних дослідників феномену лідерства в освіті, які є прихильниками різних теорій лідерства, сходяться на існуванні спільних для всіх теорій чинників (Bush T., 2011, с. 5 - 8):

1. Лідерство - це вплив; центральним елементом у багатьох визначеннях лідерства є вплив на особу або групу.

2. Лідерство грунтується на індивідуальних та професійних цінностях. Кожний член освітянської спільноти цінується як особистість та досягає успіхів через довіру, заохочення та похвалу.

3. Лідерство продукує візію закладу освіти, яскраву розумову картинку бажаного майбутнього, яка поділяється освітянською спільнотою.

Вплив на послідовників базується на власному прикладі лідера, що «виступає одним з головних і потужних інструментів сучасного управління, де саме «людська особистість», особистість лідера $є$ основним фактором впливу» (Калашнікова С. А., 2010, с. 42). Власний приклад створює довіру до лідера, «для того, щоб в організації виникла довіра, iii лідер повинен бути сам гідним довіри» (Кові С., 2013, с. 206).

Тож, погоджуючись з авторами (Єфімова С. М., Королюк С. В., 2011, с. 22 - 23), можна констатувати наступне:

- $\quad$ лідерство вважається результатом динаміки міжособистісних стосунків, а не діяльністю однієї особи;

- міжособистісні стосунки грунтуються на довірі й відкритості;

- $\quad$ керівний склад школи не просто ставить завдання, а дає можливість працівникам діяти на власний розсуд;

- $\quad$ рамки лідерства розширюються та крім учителів охоплюють також інші категорії у школі, створюючи загальношкільну командну культуру;

- $\quad$ лідерство не започатковують у наказовому порядку, а розвивають;

- $\quad$ головним критерієм при визначенні лідерів у групах є кваліфікація і досвід, а не формальна посада;

- $\quad$ лідерство не зосереджується на конкретних посадах чи ролях, воно динамічне і переходить від однієї особи до іншої, внаслідок чого «владна дистанція» чи відмінність між «лідерами» і «послідовниками» зменшується.

Запровадження лідерської парадигми в управлінні ЗСО характеризується посиленням значення горизонтальних зв'язків, делегуванням повноважень, фокусуванням на таланті, спроможності співробітників, їх компетентностях. Як наслідок зростає потенціал та якість взаємостосунків у ЗСО.

Модель послідовних кроків С. Кові. Для створення та реалізації Концепції застосуємо модель послідовних кроків «Чотири імперативи лідерства» Стівена Кові (Кові С., 2013, с. 204 - 226). Вона має чотири етапи:

1. Вселяти довіру (оцінюється рівень існуючої довіри у ЗСО, аналізуються проблемні місця, які породжують недовіру. Коли співробітники відчувають, що їх розуміють та приймають такими, якими вони є, бачать позитивний особистий приклад керівника, який їх цінує та з яким у них гарні стосунки, то стають більш відкритими до впливу).

2. Проясняти мету (з'ясовується місія, візія, стратегія 3СО, очікування від кожного співробітника). «Людина, яка не знає місію, візію чи стратегію школи, або не знає, у чому полягає їі роль у їх реалізації, ніколи не зрозуміє, «чому» ï просять про те, про що просять, і не буде відчувати ентузіазм по відношенню до цієї роботи» (Кові С., 2013, с. 211).

3. Налаштовувати системи (відбувається налаштування та узгодження підсистем ЗСО із напрацьованими місією, візією, стратегією розвитку. Це підсистеми, які забезпечують залучення, розстановку, винагороду та розвиток співробітників. Налаштування потребують і підсистема ресурсів, в тому числі бюджет, і підсистема комунікацій тощо).

4. Вивільняти таланти: лідерство - це мистецтво вивільнення можливостей цільної особистості для надихаючої та значимої мети. У ЗСО «лідерство пов'язано з тим, щоб знайти сильні сторони вчителів та адміністраторів - їх таланти, їх голоси - і потім дозволити їм злетіти до вершин. Воно пов'язано з повним «включенням» всієї «цілої людини» - ii серця, розуму, тіла і духу. Воно також пов'язано з оптимальним розвитком обдарувань учнів та вивільненням їх талантів» (Кові С., 2013, c. 222).

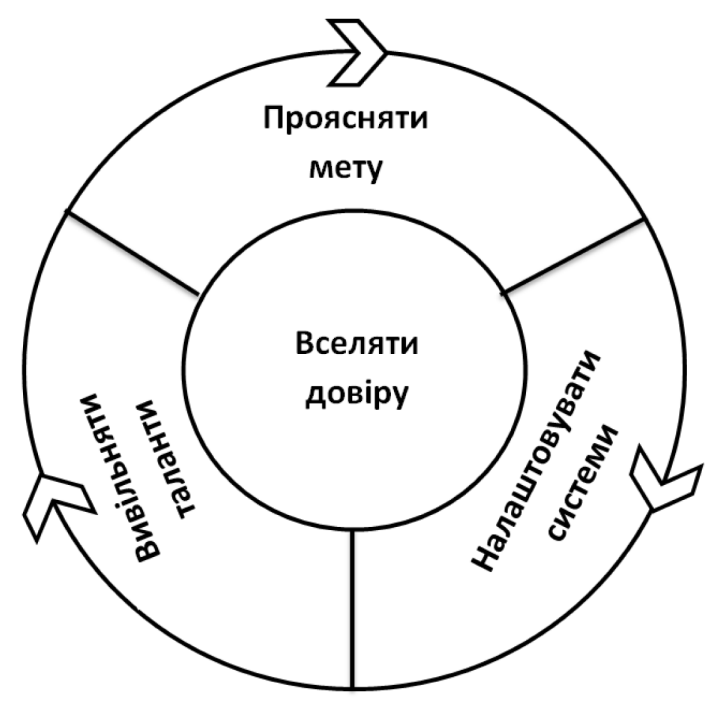

Pис. 1. Модель послідовних кроків Стівена Кові

Зростанню рівня довіри у ЗСО сприятиме обгрунтування необхідності розроблення Концепції та прийняття рішення про це на основі консенсусу. Ще одним доцільним кроком має бути проведення комплексного моніторингу діяльності 3СО та умов 
його функціонування на самому початку роботи над Концепцією, щоб встановити точку відліку для оцінки майбутніх результатів.

Таким чином, беручи за основу модель послідовних кроків, ми можемо визначити структуру та алгоритм розробки та реалізації Концепції.

Розробка Концепції розвитку ЗСО. Розуміючи під концепцією «певний спосіб розуміння, трактування предмету, явища, процесу, основну точку зору на предмет чи явище; керівну ідею для iх систематичного висвітлення» (Концепція), констатуємо, що у Концепції ми робимо спробу спроектувати майбутнє ЗСО, стратегію його дій, а тому важливо зрозуміти філософські основи діяльності ЗСО. Більшість Концепцій розвитку ЗСО на пострадянському просторі, представлених у мережі Інтернет, мають спільні елементи структури, серед яких - цілі та завдання, пріоритети розвитку ЗСО та очікувані результати від впровадження Концепції. Деякі ЗСО долучають до цього списку свою місію та візію, інші - шляхи реалізації Концепції, перспективні плани розвитку школи, перелік ресурсів, необхідних для розвитку ЗСО.

Але, враховуючи те, що Концепція істотно відрізняється від теорії не тільки своєю незавершеністю, але й недостатньою верифікованістю, це певний проект майбутнього ЗСО, визначення стратегії його розвитку, уявляється можливим визначитися з наступними складовими структури Концепції: місія, візія, мета, завдання, пріоритетні напрями діяльності ЗСО та очікувані результати (див. рис. 2).

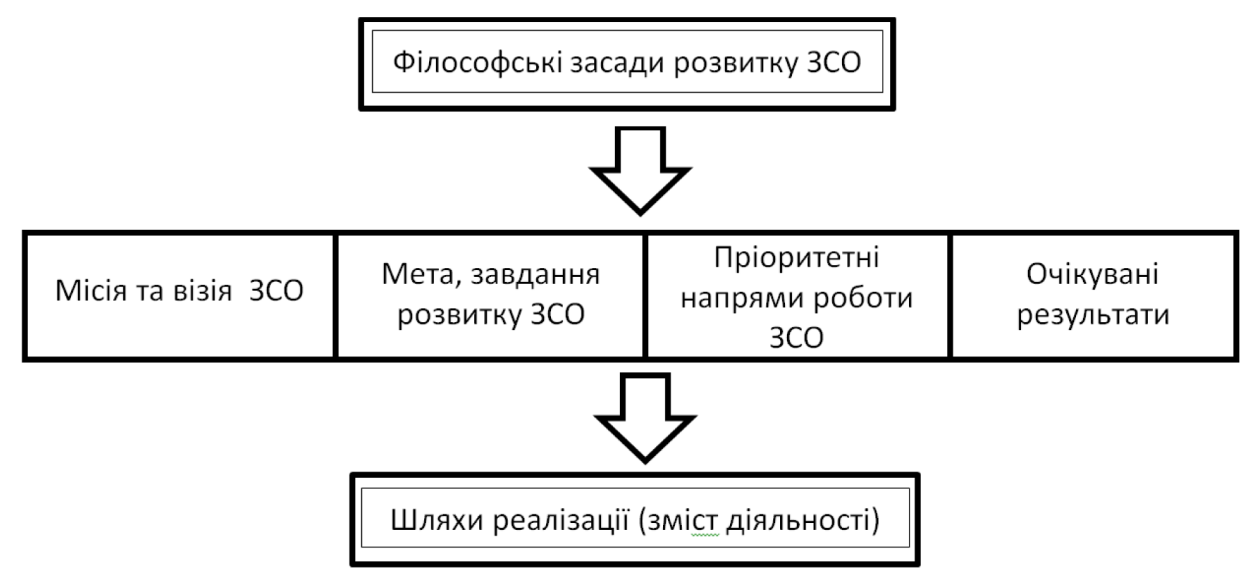

Рис. 2. Алгоритм розробки та реалізації Концепцї розвитку закладу середнвої освіти

Концепція створюється на основі філософських засад діяльності та розвитку ЗСО. Місія визначає чітко виражену причину існування $3 \mathrm{CO}$, деталізує iï статус і забезпечує напрям і орієнтири для визначення цілей і стратегій на різних організаційних рівнях. Вироблені на основі місії цілі служать як критерії для всього подальшого процесу ухвалення управлінських рішень. Якщо керівники не знають, яка основна мета їх організації, то у них не буде логічної точки відліку для вибору кращої альтернативи. «Місія - це не пункт призначення, це причина відправитися у подорож» (Кові С., 2013, с. 208).

Візія, як «віртуальний образ бажаного майбутнього стану, ідеал або амбітна мрія» (Conger J., 1989, c. 38) - це завжди дещо більше, ніж захоплююча ідея. Рушійною силою найбільш успішних організацій є зовсім не бажання досягти цілей та планових показників. Вони досягають успіху завдяки відчуттю причетності та довіри своїх співробітників.

Сучасна вимога до керівників ЗСО - сконцентрувати увагу та зусилля на розробці перспективної візії своїх шкіл, а не на плануванні діяльності. Одних стратегій вже замало, вони не забезпечують залучення співробітників, у яких не формується сильної емоційної прихильності до стратегій. Керівники-лідери повинні вийти за межі відповіді на запитання «що?» для того, щоб створити «організації, з якими працюючі у них люди можуть ідентифікувати себе, приналежністю до яких вони можуть разом пишатися і яким вони готові бути відданими» (Бойетт Дж., Бойетт Дж., 2009, с. 26 - 27).

Стратегія розвитку ЗСО, в свою чергу, містить мету, завдання, ключові цінності, пріоритетні напрямки діяльності ЗСО. Керуючись поставленою метою, управлінці визначають напрями діяльності та критерії оцінювання внеску кожного співробітника для її досягнення. Задекларовані очікувані результати від запровадження Концепції накреслюють критерії, за якими визначається успішність її реалізації.

Визначивши структуру Концепції, можемо запропонувати алгоритм їі розробки та реалізації:

1. На етапі розробки Концепції:

- обгрунтування необхідності розробки Концепції та прийняття відповідного рішення;

- проведення комплексного моніторингу діяльності ЗСО та умов його функціонування;

- визначення ідеї ЗСО, його місії, візії, стратегії розвитку, основних принципів діяльності, цінностей;

- опис очікуваних результатів;

- попередня експертиза Концепції (на актуальність, цілісність, реалістичність, технологічність та контрольованість). 
2. На етапі реалізації Концепції:

- створення стандартів діяльності ЗСО на засадах лідерства, критеріїв для оцінки результатів;

- залучення до співпраці всіх зацікавлених сторін, утворення команд у 3СО;

- організація навчання співробітників, створення дискусійних майданчиків;

- визначення змісту діяльності ЗСО на засадах лідерства;

- проведення щоквартального моніторингу та аналізу діяльності 3СО;

- щорічна експертиза Концепції (на актуальність, цілісність, реалістичність, технологічність та контрольованість).

Необхідно підкреслити, що даний алгоритм при впроваджені у життя не повинен мати лінійного характеру. Виконання тих чи інших кроків може відбуватися паралельно, в хаотичній послідовності, так само як і етапи розробки та реалізації можуть чергуватися та взаємодоповнювати один одний. 3 плином часу, здобувши досвід, шкільна спільнота може відчути потребу у коригуванні тих, чи інших положень Концепції.

Висновки. Концепція розвитку ЗСО є потужним інструментом у діяльності колективу школи, спрямованим на визначення ідеї закладу освіти, розуміння його місця, призначення у суспільстві.
Таким чином, для створення Концепції ми повинні визначитися з філософськими засадами розвитку 3СО, місією, візією, конкретизувати мету та завдання, окреслити пріоритетні напрями та чітко уявляти результати розвитку ЗСО. На основі цього вибудовується стратегія реалізації Концепції, складаються перспективні плани, здійснюється моніторинг та діагностика діяльності ЗСО, вносяться зміни до структури тощо.

Запровадження лідерської парадигми в управління ЗСО є критично важливим тоді, коли з'являється необхідність у перетвореннях. Колектив школи, здійснюючи перетворення, повинен зрозуміти, проаналізувати основні цінності та мету ЗСО, організаційну культуру та порядки, специфічні цілі, які склалися до трансформації. При цьому необхідно звернути увагу на стратегії та негативні переконання, які стримують подальший розвиток школи.

Лідерство грунтується на цінностях та переконаннях всього ЗСО, тож необхідно зробити ці цінності та переконання зрозумілими та ясно вираженими. Школи повинні стати лідерськими організаціями, які заохочують та розвивають лідерство на всіх рівнях, створюють відповідну організаційну культуру, де працівники сповідують загальну мету та здатні досягати високих результатів.

\section{Література}

1. Бойетm Дж., Бойетm Дж. Путеводитель по царству мудрости: лучшие идеи мастеров управления. - 3-е изд., испр. и доп. / [Пер. с англ. А. А. Калинина]. - М.: ЗАО «Олимп-Бизнес», 2009. - 416 с.

2. $\boldsymbol{\Gamma р и г о р а ш ~} \boldsymbol{B} . \boldsymbol{B}$. Концепція розвитку в системі стратегічного планування школи [Електронний ресурс] / В. В. Григораш // Актуальні проблеми державного управління, педагогіки та психології. - 2013. Вип. 2. - С. 241 - 245. - Режим доступу: http://nbuv.gov.ua/j-pdf/apdyptp_2013_2_50.pdf.

3. Гриневич Л. М. Вітчизняна теорія про розвиток освіти в Україні у контексті євроінтеграційних процесів / Л. М. Гриневич // Педагогічний процес: теорія і практика. - № 1-2. - 2015. - С. 5 - 10.

4. $\boldsymbol{G \phi i м о в а ~} \boldsymbol{C}$. М., Королюк $\boldsymbol{C}$. В. Лідерство та інклюзивна освіта: навчальний курс та методичний посібник / За заг. ред. Колупаєвої А. А. - К.: ТОВ «Видавничий дім «Плеяди», 2011. - С. 22 - 23.

5. Калашнікова $\boldsymbol{C}$. $\boldsymbol{A}$. Освітня парадигма професіоналізації управління на засадах лідерства: монографія / С. А. Калашнікова. - К.: Київськ. ун-т імені Бориса Грінченка, 2010. - 380 с.

6. Кови $\boldsymbol{C}$. Лидер во мне: Как школы и родители по всему миру помогают детям стать великими / Стивен Кови; [пер. с англ. М. Мацковской]. - 2-е изд. - М.: Манн, Иванов и Фербер; Эксмо, 2013. - 304 с.

7. Конщепція [Електронний ресурс]. - Режим доступу: http://dic.academic.ru/dic.nsf/ enc philosophy $/ 2537$

8. Линъов $\boldsymbol{K}$. $\boldsymbol{O}$. Підготовка керівника закладу середньої освіти в університетах України на засадах лідерства / К. О. Линьов // Вища освіта України: Теоретичний та науково-методичний часопис. - № 3. Додаток 1: Інтеграція вищої освіти і науки. - К., 2015. - С. 128-132. - С. 130.

9. Максвелл Дж. Розвинь лідера в собі / Пер. з англ. Н.Гербіш. - К.: Брайт Стар Паблішинг, 2013. - 184 с.

10. Оуэн $\boldsymbol{X}$., Ходжсон В., Газзард $\boldsymbol{H}$. Призвание - лидер: Полное руководство по эффективному лідерству / Пер. с англ. - Днепропетровск: Баланс Бизнес Букс, 2005. - 384 с.

11. Проект Концепції розвитку освіти України на період 2015 - 2025 років [Електронний ресурс]. Режим доступу: http://old.mon.gov.ua/ua/pr-viddil/1312/1390288033/1414672797/

12. Belinskaja L., Pauliene R. Overwiew of the Current Leadership Theories: What It Means to Lead? [Електронний ресурс] / L. Belinskaja, R. Pauliene // 7th International Scientific Conference "Business and Management 2012”, 2012. - Режим доступу: http://bm.vgtu.lt/index.php/bm/bm_2012/paper/view/89, DOI: 10.3846/bm.2012.042.

13. Bush T. Theories of Educational Leadership and Management / Fourth Edition. - London: SAGE Publications, Inc., 2011. - 232 p.

14. Conger J. The Charismatic Leader: Behind the Mystique of Exceptional Leadership. - San Francisco: Jossey-Bass, 1989. 


\section{КОНЦЕПЦИЯ РАЗВИТИЯ ОБЩЕОБРАЗОВАТЕЛЬНОГО УЧЕБНОГО ЗАВЕДЕНИЯ НА ОСНОВЕ ЛИДЕРСТВА}

Линев Константин, кандидат наук по государственному управлению, доцент, профессор кафедры управления, Киевский университет имени Бориса Гринченка, пр-т М. Тимошенко 13 б, 04212 г. Киев, Украина, k.lynov@kubg.edu.ua

Статья посвящена определению специфики разработки Конщепщии развития общеобразовательного учебного заведения в Украине на основе лидерства. Опираясь на модель последовательных шагов «Четыре императива лидерства» Стивена Кови - старшего, автор предлагает структуру Коцепиии развития общеобразовательного учебного заведения и алгоритм ее разработки и реализации. Акцентируется внимание на том, что внедрение лидерской парадигмы в деятельность общеобразовательного учебного заведения характеризуется усилением значения горизонтальных связей, делегированием полномочий, фокусированием на талантах, способностях сотрудников, их компетентностях.

Ключевые слова: визия; Кониепиия развития общеобразовательного учебного заведения; лидерство; мисия; модель последовательных шагов; общеобразовательное учебное заведение.

\section{THE CONCEPT OF INSTITUTIONS OF SECONDARY EDUCATION DEVELOPMENT ON THE BASIS OF LEADERSHIP}

Lynov Konstantin, Phd in Public Administration, Chair of Management, Borys Grinchenko Kyiv University, 13-b Tymoshenko st., 04212 Kyiv, Ukraine, k.lynov@kubg.edu.ua

Article reviews approaches of creation the Concept of institutions of secondary education development in Ukraine. It is noted that implementation of leadership paradigm in the management of secondary education is critically important according to the changes and challenges. Motivating employees to leadership development and taking initiative suggests that they have a sense of involvement in results of collective activities. All mentioned above creates culture of freedom and responsibility in the of secondary education institutions, helps to develop individuals as an administrator, teacher and student, forms their willingness to build life in the twenty-first century. Author relies on the model of sequential steps «The 4 Imperatives of Great Leaders» by Stephen R. Covey that determines the structure of development concept and its algorithm in development and implementation. The most difficult to practice of management in school is the assertion that the universal methods of leadership implementation are available. Each school must create its own method to fit the specific needs of the school and its organizational culture. The development concept is a powerful tool in the work of school staff, aimed to identify idea of educational institution, it's of the place and destination in society. To create Concept author proposes to determine the philosophical foundations of the secondary education institution, its mission, vision, goals and objectives, priorities and idea of development results. Development Concept helps institutions to build strategy, implement the concept, build long-term plans, monitor and diagnose secondary education institutions.

Key words: Concept of institution of secondary education development; institution of secondary education; leadership; mission; model of sequential steps; vision.

Стаття надійшла до редакції 10.03.2015 Прийнята до друку 31.03.2016 